\title{
Trace Elements in Chromites from Kimberlites and Related Rocks: Relation to Temperature and Mantle Composition
}

\author{
Yao, S. ${ }^{1}$, Griffin, W.L. ${ }^{1,2}$ and O'Reilly, S.Y.
}

1. GEMOC National Key Centre,, School of Earth Sciences, Macquarie University, NSW 2109, Australia

2. CSIRO Exploration and Mining, P.O. Box 136, N. Ryde, NSW 2113, Australia

Since the work of Irvine $(1965,1967)$, the use of chromite as a petrogenetic indicator has been extensively studied. However, most of the investigations were focused on chromites in Alpine-type peridotites, chromitites associated with ophiolite suites, and chromites from komatiites and other ultramafic volcanic rocks. Fewer studies have focused on chromites from kimberlites and related rocks. Furthermore, former studies were mainly based on major elements in chromites. This study aims to use trace elements in chromites from kimberlites and related rocks to examine mantle processes.

About 1500 chromites from 47 kimberlite, lamproite and lamprophyre localities world-wide have been analysed to determine their major and trace element contents by using electron microprobe and laser ablation microprobe ICP-MS, respectively, in the GEMOC National Key Centre at Macquarie University. Chromites analysed are heavy mineral concentrates embedded in epoxy resin and polished and their sizes are typically $0.5-1 \mathrm{~mm}$ in diameter, with a few larger than $1 \mathrm{~mm}$. Chemical compositions reported here represent analyses of the cores of grains. Chromites from xenoliths have been analysed in-situ using thick polished sections.

Irvine (1967) and many other authors pointed out that chromites in ultramafic volcanic rocks crystallise in the early stage of magmatic crystallisation. By comparison of chemical compositions of chromite macrocrysts and chromites in mantle-derived xenoliths in kimberlites, Schulze (1996) concluded that all chromites in southern African kimberlites are xenocrysts derived by disaggregation of mantle peridotites. Regardless of their origin, chromites in kimberlites, lamproites and lamprophyres are believed to be equilibrated with mantle olivine because these rocks are directly mantle-derived.

There are some good inter-element correlations observed in chromites from kimberlites and related rocks. As shown in Fig.1, all chromites show a positive correlation between Co and $\mathrm{Zn}$ and negative correlation between $\mathrm{Co}$ and $\mathrm{Ni}$. A negative correlation also exists between $\mathrm{Zn}$ and $\mathrm{Ni}$ (not shown).

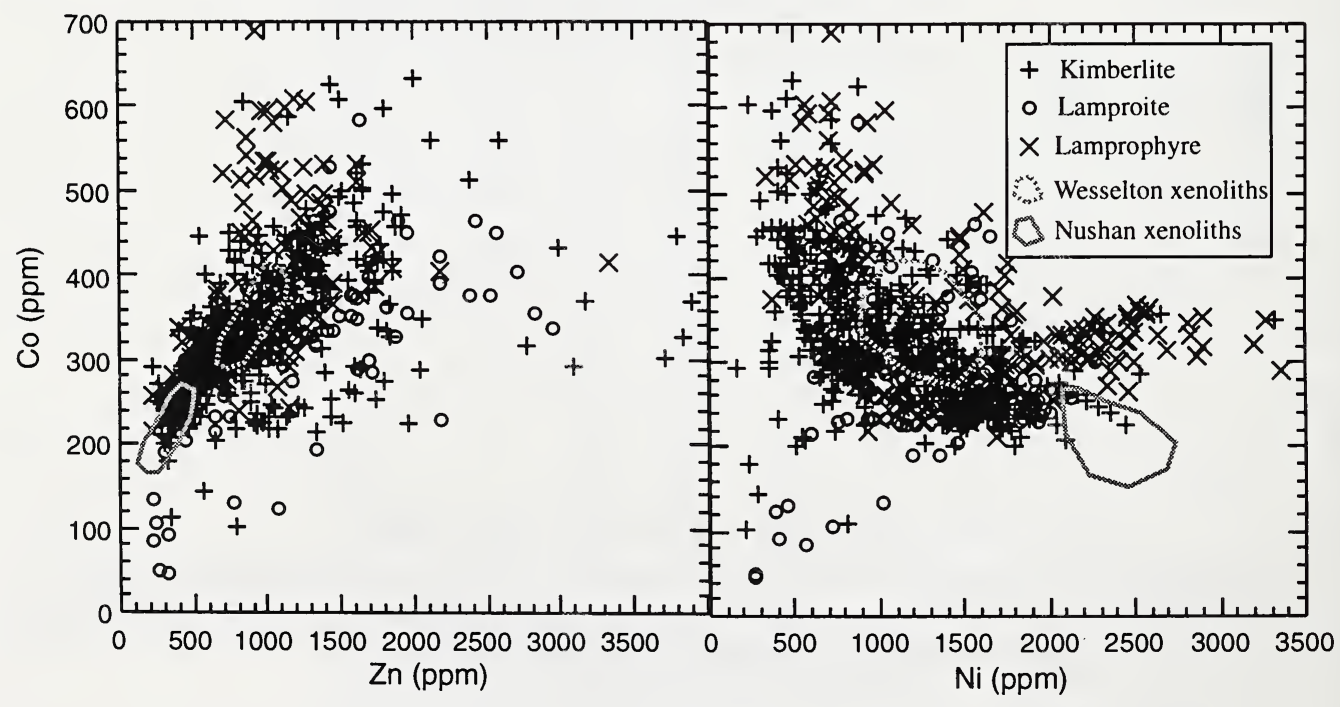

Fig. 1. Co-Zn-Ni relationships in mantle-derived chromites. 
Some analyses of $\mathrm{Cr}$-spinel (low $\mathrm{Cr}$ ) in xenoliths from Nushan alkaline basalt, southeastern China and chromites in xenoliths from Wesselton kimberlite, South Africa show the same correlations, within single suites (Fig.1). This implies that most chromite macrocrysts in kimberlites and related rocks are xenocrysts derived by disaggregation of mantle peridotites and captured by magmas ascending through the mantle sections. Those scattered off the main trends are believed to be magmatic or modified (metasomatised or metamorphosed) chromites. Chromites along the trends are defined as a "Mantle Array", which represents chromites equilibrated with mantle olivine.

Zn contents are temperature-dependent (Griffin et al., 1994; Ryan et al., 1996), and Co shows a good correlation with $\mathrm{T}_{\mathrm{Zn}}\left({ }^{\circ} \mathrm{C}\right)$ derived from $\mathrm{Zn}$ composition, therefore suggesting the Mantle Array is controlled by temperature. The overall negative correlation of $\mathrm{Ni}$ with $\mathrm{Zn}$ indicates that $\mathrm{Ni}$ contents in chromites are also controlled by temperature. The behaviour of Mantle Array chromites is attributed to the partitioning of these elements between chromite and mantle olivine, which serves as a reservoir of these elements. Generally, the Mantle Array chromites can be defined on 3 axes: $\mathrm{Zn}, \mathrm{Co}$ and Ni.

If most chromites in kimberlites and related rocks are xenocrysts from mantle rocks and have equilibrated with mantle olivine, the chemical composition of these chromites should record mantle composition as well as temperature. In order to test whether chromites record differences in the chemical composition of the lithosphere related to age or tectonic position, we have classified the localities according to the age of the last tectonothermal modification of the crust through which these kimberlites and related rocks penetrated, using a version of the scheme proposed by Janse (1984). "Archon" represents a craton stablised in Archean time with latest crustal modification >2.5 Ga. "Protons" are cratons with latest crustal modification before $1000 \mathrm{Ma}$. "Tectons" are basically younger tectonic units, mainly Phanerozoic in age.

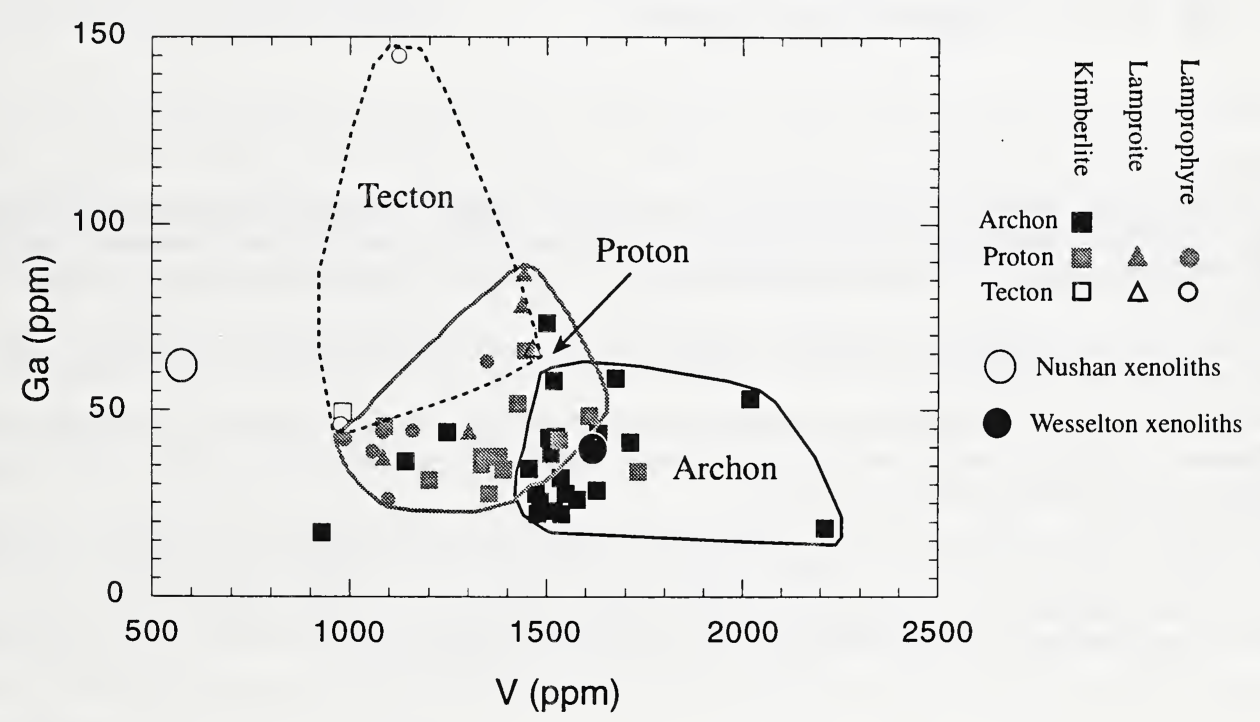

Figure 2. Ga vs $\mathrm{V}$ in Mantle-Array chromites

The trace elements of mantle-array chromites show differences among different tectonic environments. Chromites from Archons contain significantly higher V than those from Protons and Tectons, and chromites from Tectons have relatively higher Ga than those from Protons although they have similar V contents (Fig. 2). Ga is positively correlated with $\mathrm{Al}^{\#}$, and the higher $\mathrm{Al}$ and $\mathrm{Ga}$ in Tecton chromites reflects the enrichment of Phanerzoic mantle in $\mathrm{Al}$ relative to Proterozoic and Archean mantles. The higher $\mathrm{V}$ in Archon chromites correlates positively with $\mathrm{Cr}^{\#}$, which is an indicator of the degree of depletion of the mantle. Chromites from Archons tend to have high $\mathrm{Nb}$ and $\mathrm{Nb} / \mathrm{Zr}$, while those from Protons show a much greater spread in $\mathrm{Zr}$ contents and $\mathrm{Nb} / \mathrm{Zr}$ (Fig. 3). 
Chromites from Tecton environments, and all chromites from lamprophyres, tend to have low $\mathrm{Nb}$ and $\mathrm{Zr}$. These differences may be related to time-integrated differences in metasomatic style, related to tectonic setting; chromites from xenoliths in the Wesselton kimberlite ( $\mathrm{S}$. Africa) have high $\mathrm{Nb}$ contents which can be related to observed phlogopite-related metasomatism.

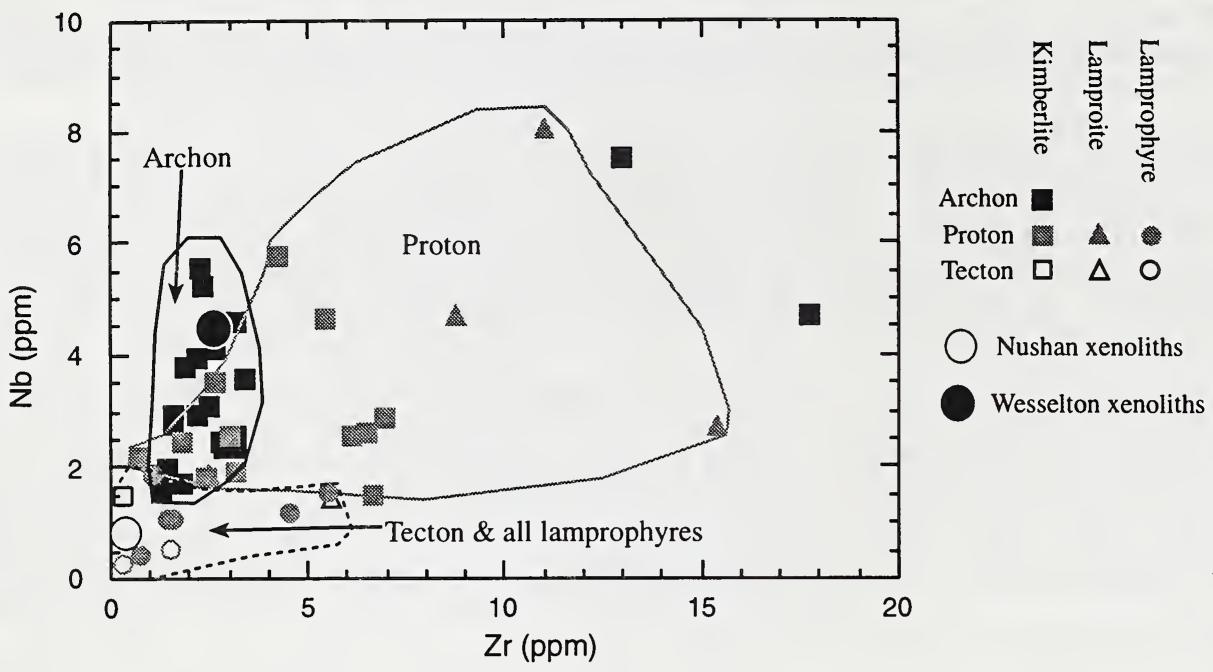

Figure 3. $\mathrm{Nb}$ vs $\mathrm{Zr}$ in Mantle-Array chromites

\section{References}

Griffin, W.L., Ryan, C.G., Gurney, J.J., Sobolev, N.V. and Win, T.T. (1994), Chromite macrocrysts in kimberlites and lamproites: Geochemistry and origin, in H.O.A. Meyer and O.H. Leonardos (Eds) Kimberlites, Related Rocks and Mantle Xenoliths. CPRM Special Publication 1/A, pp.366-377, Companhia de Pesquisa de Recursos Minerais, Brasil.

Irvine, T.N., 1967, Chromian spinel as a petrogenrtic indicator. Part 2: Petrogenetic applications. Canadian Journal of Earth Sciences, Vol. 4, pp.71-103.

Janse, A.J.A., 1994. Is Clifford's Rule still valid? Affirmative examples from around the world. In H.O.A. Meyer and O. Leonardos (eds) Diamonds: characterization, genesis and exploration, CPRM Spec. Publ. 1A/93, Dept. Nacional da Prod. Mineral., Brazilia, 215-235.

Ryan, C.G., Griffin, W.L. and Pearson, N.J., (1996), Garnet geotherms: Pressure-temperature data from Cr-pyrope garnet xenocrysts in volcanic rocks, Journal of Geophysical Research, Vol.101, No.B3, pp.5611-5625.

Schulze, D.J., 1996, Chromite macrocrysts from southern African kimberlites: mantle xenolith sources and postdiamond re-equilibration. Africa Geoscience Review, Vol.3, No.2, pp.203-216. 